\title{
Revolusi Mental Melalui Penguatan Pendidikan Karakter untuk Siswa Berkebutuhan Khusus di Kota Mataram
}

\author{
Zaini Bidaya', Silfiah Miulan Dari²
}

\author{
${ }^{1}$ Pendidikan Pancasila dan Kewarganegaraan, Universitas Muhammadiyah Mataram, hajizainibidaya42@gmail.com \\ ${ }^{1}$ Pendidikan Pancasila dan Kewarganegaraan, Universitas Muhammadiyah Mataram, silfiahmilundari45@gmail.com
}

INFO ARTIKEL
Riwayat Artikel:
Diterima: 14 September
2020
Disetujui: 30 September
2020

Kata Kunci:

Revolusi mental

Pendidikan karakter

Siswa

Berkebutuhan khusus

\begin{abstract}
ABSTRAK
Abstrak: Melalui pendidikan karakter, siswa pada umumnya yang bersekolah di sekolah inklusi dituntut memiliki empati dan pertimbangan yang tinggi sehingga dapat merangkul teman berkebutuhan khusus dan membantu guru memberikan layanan pendidikan yang optimal. Tujuan yang dicapai adalah untuk menjelaskan revolusi mental melalui penguatan pendidikan karakter untuk siswa berkebutuhan khusus di kota Mataram. Metode pelitian adalah kualitatif melalui pendekatan diskriptif dengan menentukan informan secara purposive sampling, sumber data terdiri dari data primer dan sekunder. Teknik pengumpulan data yang digunakan adalah observasi, wawancara, dan dokumentasi dengan teknik analisis melalui reduksi data, display data, dan penarikan kesimpulan. Hasil penelitian menunjukan bahwa Hasil peneilitian ini memberikan dampak bahwa revolusi mental melalui penguatan pendidikan karakter untuk siswa berkebutuhan khusus dapat dilakukan melalui program-program yang terintegrasi dengan proses kegaitan pebelajaran di sekolah meliputi kelima nilai utama penguatan pendidikan karakter yaitu nilai religius, nasionalisme, gotong royong, integritas, dan mandiri melalui program pembelajaran akademik, program keterampilan, program khusus, pengembangan diri dan ekstarakulikuler, budaya dan karakter bangsa. Hambatan yang terjadi adalah kurangnya dukungan atau partisipasi orang tua dalam proses pendidikan karakter pada anak yang bisa menjadi permasalah ataupun hambatan bagi siswa dalam penerapan nilai karakter di lingkungan keluarga dan masyarakat. Jadi revolusi mental untuk siswa berkebutuhan khusus ini sangat urgen untuk tetap memberikan pelayanan pendidikan yang layak.
\end{abstract}

\begin{abstract}
Through character education, students in general who attend inclusive schools must have high empathy and consideration so that they can embrace friends with special needs and help teachers provide optimal educational services. The goal achieved was to explain the mental revolution by strengthening character education for students with special needs in Mataram. The research method is qualitative through a descriptive approach by determining informants by purposive sampling; the data source consists of primary and secondary data. Data collection techniques were observation, interviews, and documentation with analysis techniques through data reduction, data display, and concluding. The results show that the results of this study have an impact that mental revolution through strengthening character education for students with special needs can be carried out through programs that are integrated with the process of learning activities in schools covering the five main values of strengthening character education, namely religious values, nationalism, cooperation, integrity, and independence through academic learning programs, skills programs, special programs, self-development, and extracurricular activities, culture and national character. The obstacle that occurs is the lack of support or parental participation in character education in children, which can be a problem or impediment for students in applying character values in the family and community environment. So this mental revolution for students with special needs is very urgent to provide appropriate educational services.
\end{abstract}

\section{A. LATAR BELAKANG}

Pendidikan merupakan usaha sadar secara sistimatis untuk mencetak seseorang menjadi generasi yang berkualitas dan memiliki daya saing, karenanya pemerintah telah menjamin hak warga negara untuk mendapatkan pendidikan, dalam UU No. 20 Tahun
2003 tentang Sistem Pendidikan Nasional dijelasknan bahwa pendidikan adalah usaha sadar dan terencana untuk mewujudkan suasana belajar dan proses pembelajaran agar peserta didik secara aktif mengembangkan potensi diri untuk memiliki kekuatan spiritual keagamaan, pengandalian diri, keperibadian, kecerdasan, akhlak mulia serta keterampilan yang di 
perlukan dirinya, masyarakat, bangsa dan Negara. Maka dari itu pendidikan pada umumnya sangat penting diberikan pada seluruh kalangan masyarakat secara menyeluruh karena dengan pendidikan yang baikakan berimplikasi padapembentukan Sumber Daya Manusia (SDM) yang berkualitas dan berkarakter.

Implementasi Perpres No. 87 Tahun 2017 tentang Penguatan Pendidikan Karakter bahwa pelaksanaan program Penguatan Pendidikan Karakter terintegrasi dengan seluruh atau masing-masing materi pembelajaran yang diaktualisasikan dalam kegiatan pembelajaran di dalam kelas maupun diluar kelas.[1] lainnya menjelaskan bahwa Pendidikan karakter untuk anak berkebutuhan khusus harus diberikan kebebasan kepada anak seperti kemandirian emosional dan kemandirian sosial diamati selama proses pembelajaran dan acara di asrama. Cara ini dilakukan terus menerus dan terus menerus. Kebutuhan khusus juga diperlukan untuk meningkatkan pendidikan karakter mandiri bagi anak dengan gangguan jiwa agar anak dapat menghidupi dirinya sendiri tanpa bantuan orang lain.[2] Melalui pendidikan karakter, siswa pada umumnya yang bersekolah di sekolah inklusi dituntut memiliki empati dan pertimbangan yang tinggi sehingga dapat merangkul teman berkebutuhan khusus dan membantu guru memberikan layanan pendidikan yang optimal.[3] Pendidikan karakter dapat mempengaruhi keterampilan siswa berkebutuhan khusus.[4] Pendidikan karakter inklusif dapat diwujudkan dengan mengupgrade pembelajaran dengan pembelajaran ramah anak, empati, pembelajaran yang berpusat pada siswa, dan pembelajaran sesuai dengan kebutuhan belajar siswa.[5]

Berdasarkan hasil berbagai penelitian mereka lebih focus pada pendidikan karakter secara umum, mendidik belajar mandiri, dan pendidikan karakter dapat mempengaruhi perilaku mereka, sementara aspek penguatan pendidikan karakter untuk anak berkebutuhan khusus masih belum banyak yang menjelaskan secara detail. Hal yang akan dijelaskan dalam artikel ini adalah revolusi mental melalui penguatan pendidikan karakter untuk siswa berkebutuhan khusus di kota mataram. Revolusi mental bagi anak berkebutuhan khusus juga penting dilakukan karena mereka juga anak yang berhak mendapatkan pendidikan yang layak, dan mendapat kesejahteraan fasilitas dari Negara, selain itu kota mataram merupakan kota yang beragam terutama anak berkebutuhan khsuus.

Melihat kondisi sekarang ini dan akan datang, ketersediaan Sumber Daya Manusia (SDM) yang berkualitas dan berkarakter merupakan kebutuhan fundamental yang wajib diberikan kepada masyarakat secara holistic, baik itu dari golongan terpelajar maupun non terpelajar. Di era teknologi saat ini memunculkan berbagai persoalan moral, budi pekerti, watak atau karakter seperti: meningkatnya dekandensi moral, meningkatnya ketidak jujuran pelajar, dan masih tingginya kasus tindakan kekerasan yang terjadi antar pelajar seperti bullying dan tawuran serta berbagai fenomena lain yang menunjukan bahwa nilai-niali pancasila pada generasi penerus bangsa memudar. Salah satu cara memperbaiki kemerosotan moral dan nilainalai pancasila saat ini yaitu melakukan revolusi karakter bangsa atau revolusi mental.

Melihat kondisi seperti ini pemerintah mulai menata sistem pendidikan di Indonesia dengan memunculkan pendidikan karakter dalam semua jenjang pendidikan. Menurut Albertus pendidikan karakter adalah di berikannya tempat bagi kebebasan individu dalam menghayati nilai-nilai yang dianggap baik, luhur, dan layak di perjuangkan sebagai pedoman bertingkah laku bagi kehidupan pribadi berhadapan dengan dirinya, sesama dan Tuhan.[6] Pendidikan Karakter sebenarnya bukanlah hal sebuah kebijakan baru dalam dunia pendidikan, namun sejauh ini dalam pelaksanaannya masih kurang optimal. Hal ini disebabkan oleh berbagai faktor mulai dari penyusunan kebijakan program pendidikan karakter yang tidak berjalan dengan baik, kualitas sarana dan prasarana, kualitas dari tenaga pendidik, dan lain sebagainya.

Berdasarkan fenomena diatas maka pada tanggal o6 September 2017, Presiden Joko Widodo mengeluarkan Peraturan Presiden (Perpres) No. 87 Tahun 2017 tentang Penguatan Pendidikan Karakter. Dalam Perpres No.87 Tahun 2017 tersebut dijelaskan bahwa Penguatan Pendidikan Karakter (PPK) merupakan gerakan pendidikan di bawah tanggung jawab satuan pendidikan untuk memperkuat karakter peserta didik melalui harmonisasi olah hati, olah rasa, olah pikir, dan olah raga dengan pelibatan dan kerja sama antara satuan pendidikan, keluarga, dan masyarakat sebagai bagian dari Gerakan Nasional Revolusi Mental (GNRM).

Di dalam Perpres tersebut menunjukan keyakinan pemerintah untuk mendukung pendidikan karakter yang telah dirancang melalui kurikulum 2013. Dalam Perpres memuat beberapa tujuan dari PPK, yaitu membangun dan membekali peserta didik sebagai generasi emas Indonesia tahun 2045 dengan jiwa Pancasila dan pendidikan karakter serta mengembangkan platform pendidikan nasional yang meletakkan pendidikan karakter sebagai jiwa utama dalam penyelenggaraan pendidikan dengan dukungan pelibatan publik yang dilakukan melalui pendidikan jalur formal, nonformal, dan informal dengan memperhatikan keberagaman budaya Indonesia.

Berdasarkan hal tersebut, maka pendidikan karakter bangsa harus di berikan pada semua peserta didik disekolah, termasuk anak berkebutuhan khusus yang notabennya anak non normal yang juga berhak untuk mendapatkan pendidikan layaknya anak-anak normal, karenanya gerakan Penguatan Pendidikan Karakter (PPK) tidak hanya dilaksanakan pada sekolah leguler (SD/SMP/SMA/SMK) tetapi juga dilaksanakan di 
Sekolah Luar Biasa (SLB)/Sekolah Khusus (SKh)/Sekolah Inklusi dimana di sekolah-sekolah tersebut peserta didiknya menyandang kelainan fisik, emosional, mental, intelektual, dan sosial atau yang sering disebut Anak Berkebutuhan Khusus (ABK).

Bagi Anak berkebutuhan khusus, pendidikan dilakukan dengan pelayanan secara khusus, yang berbeda dengan anak pada umumnya karena mengalami hambatan dalam belajar dan perkembangan sehingga begitu rentannya dimanfaatkan oleh orang-orang yang tidak bertanggung jawab. Menurut Kementerian Pemberdayaan Perempuan dan Perlindungan anak bahwa anak berkebutuhan khusus masuk kedalam 15 kelompok anak yang rentan mengalami kekerasan. Bentuk-bentuk kekerasan yang rentan dialamipun sangat beragam seperti, kekerasan fisik, psikis, hingga hambatan-hambatan sosial seperti pelabelan negatif dan diskriminasi.[7]

Anak berkebutuhan pada umumnya bersekolah di Sekolah Luar Biasa (SLB) sesuai dengan kebutuhannya masing-masing. SLB bagian A untuk anak tunanetra, SLB bagian B untuk anak tunarungu, SLB bagian C untuk anak tunagrahita, SLB bagian D untuk anak tunadaksa, SLB bagian E untuk anak tunalaras dan SLB bagian G untuk cacat ganda.[8] Model pendidikan khusus seperti pendidikan luar biasa dengan bentuk sekolah bernama Sekolah Luar Biasa (SLB) yang berbeda dengan sekolah-sekolah pada umumnya wajib membekali peserta didiknya dengan karakter positif yang kuat sesuai dengan kadar kemampuan peserta didik. Karakter yang kuat peserta didik anak berkebutuhan khusus (ABK) dapat menghindarkan peserta didik dari kekerasan fisik/ psikis dan meningkatkan kepercayaan diri ABK yang pada akhirnya akan melahirkan optimisme untuk menjalankan kehidupan, walaupun dirinya berbeda dengan anak-anak pada umumnya. SLB Negeri 1 Kota Mataram merupakan salah satu sekolah luar biasa yang diperuntukkan bagi anak berkebutuhan khusus, yang terletak di jalan Adi Sucipto No. 42 Ampenan Mataram, kelurahan Pejarakan Karya Kecamatan Ampenan Kota Mataram Provinsi Nusa Tenggara Barat yang didirikan tahun 2005.

Dari observasi awal, SLB Negeri 1 Kota Mataram telah di tunjuk oleh pemerintah sebagai sekolah rintisan Pendidikan Budaya dan Karakter Bangsa, kewirausahaan dan ekonomi kratif dengan pendekatan belajar aktif untuk membangun daya saing dan karakter bangsa dari tahun 2010 sampai tahun 2014 sehingga SLB Negeri 1 Kota Mataram telah memiliki pengalaman dalam memberikan pembinaan karakter kepada peserta didiknya dan telah mulai melaksanakan program baru yaitu penguatan pendidikan karakter sehingga nantinya peserta didik juga mempu menjadi manusia yang religius, mandiri, trampil, peduli, bertanggung jawab, berjiwa sosial sehingga dapat diterima dimasyarakat, dan dapat menjadi generasi emas Indonesia Tahun 2045 dengan jiwa pancasila dan karakter yang baik guna menghadapi dinamika perubahan di masa depan. Dengan demikian SLB Negeri 1 Kota Mataram mempunyai tanggung jawab yang lebih berat di banding sekolah pada umumnya karena pengimplementasian penguatan pendidikan karakter di SLB tidak dapat dilakukan sama dengan sekolah leguler lainnya. Dengan demikian tujuan dalam artikel ini adalah untuk menjelaskan revolusi mental melalui penguatan pendidikan karakter untuk siswa berkebutuhan khusus di kota Mataram.

\section{B. METODE PENELITIAN}

1. Metode yang digunakan

Metode penelitian yang digunakan dalam penelitian ini adalah metode kualitatif dengan pendekatan diskriptif tentang revolusi mental melalui penguatan pendidikan karakter untuk siswa berkebutuhan khusus di kota mataram

2. Subjek Penelitian

Peneliti menentukan subjek penelitian berdasarkan tujuan yang akan diteliti tentang menelaskan revolusi mental melalui penguatan pendidikan karakter untuk siswa berkebutuhan khusus di kota mataram. Maka, subjek penelitiannya yaitu Kepala Sekolah, guru kelas, waka kurikulum, dan waka kesiswaan.

3. Teknik Pengumpulan Data

Untuk memperoleh data dan informasi dalam penelitian ini, maka teknik pengumpulan data dalam penelitian ini mengunakan teknik observasi, wawancara, dan dokumentasi.

4. Jenis dan Sumber Data

Jenis data yang digunakan dalam penelitian ini adalah jenis data kualitatif yang merupakan data yang diperoleh dalam sebuah penelitian yang bukan berbentuk angka, dengan sumber data primer dan sekunder.

\section{Teknik Analisis Data}

Analisis data merupakan proses mencari dan menyusun secara sistimatis data yang diperoleh dari hasil wawancara, catatan lapangan, dan dokumentasi dengan cara mengorganisasikan data kedalam kategori, menjabarkan kedalam unit-unit, melakukan sentesa, menyusun kedalam pola, memilih mana yang penting, yang akan dipelajarai, dan muncul kesimpulan sehingga mudah di pahami oleh diri sendiri maupun orang lain. Dalam proses analisis interaktif terdapat 4 komponen harus dipahami oleh peneliti yaitu :

Pertama, pengumpulan data. Pada penelitian ini, peneliti berusaha untuk mengumpulkan data secara mendetail di SLB Negeri 1 Kota Mataram dengan menggunakan metode observasi, wawancara dan dokumentasi. Kedua, Reduksi data. Reduksi data diartikan sebagai proses merangkum, memilih hal-hal yang pokok, memfokuskan pada hal-hal yang penting, dan transformasi data kasar yang muncul dari catatancatatan tertulis di lapangan. Ketiga, display data. Display data adalah pendeskripsian sekumpulan informasi 
tersusun yang memberikan kemungkinan adanya penarikan kesimpulan dan pengambilan tindakan. Dalam penelitian kualitatif, penyajian data bisa dilakukan dengan bentuk uraian singkat, bagan, hubungan dengan kategori, flowchart dan sejenisnya. Penyajian data kualitatif disajikan dalam bentuk teks naratif. Keempat, Penarikan kesimpulan/verifikasi. Penarikan kesimpulan/verifikasi merupakan kegiatan akhir analisis data, penarikan kesimpulan berupa kegiatan interprestasi, yaitu menemukan makna data yang telah disajikan. Kesimpulan dalam penelitian kualitatif merupakan temuan baru yang sebelumnya belum pernah ada pada penelitian lain.

\section{HASIL DAN PEMBAHASAN}

\section{Program Kegiatan Penguatan Pendidikan Karakter untuk anaak berkebutuhan khsusus di SLB Negeri 1 Kota Mataram}

Pengutan pendidikan karakter anak berkebutuhan khusus dirancang sebagai praktik yang menyeluruh yakni sepanjang proses belajar di sekolah. Gerakan penguatan pendidikan ABK dilaksanakan mulai hari pertama masuk sekolah hingga peserta didik lulus, sesuai dengan Peraturan Presiden Nomor 87 Tahun 2017. Hari pertama peserta didik masuk sekolah, orangtua harus mengantar dan berinteraksi dengan seluruh warga sekolah, sehingga diharapkan pendidikan karakter positif sudah bisa tumbuh sejak awal pengenalan lingkungan sekolah.Hal ini di dukung dengan pernyataan Waka Kurikulum bahwa :

"untuk melakukan penguatan pendidian karakter mulai di ajarkan pada siswa sejak anak itu masuk sekolah saat penerimaan murit baru, dimana ketika orang tua dan siswa mendaftar kesekolah disitu diajarkan baimana mengucap salam dan menjawab salam, bersikap sopan dan itu diawal-awal masuk sekolah".

Dalam menjalankan implementasi Penguatan Pendidikan Karakter, sekolah telah membuat dan melaksanakannya program penguatan pendidikan karakter melalui program kegiatan disekolah yang dirancang khususyang sesuai dengan nilai utama pengutan pendidikan karakter dan terintekrasi dengan proses pembelajaran hal ini pula berdasarkan dengan pernyataan kepala sekolah bahwa :

"pendidikan karakter disini bukan berarti berdiri sebagai mata pelajaran, tetepi mesti diajarkan kepada seluruh warga sekolah utamanya anak-anak kita, hal ini sudah terintegrasi melalui program pembelajaran di masing-masing kelas disemua mata pelajaran dan semua program-program kegiatan yang ada di sekolah dan program penguatan pendidikan karakter sudah menjadi program tahunan yang wajib dilaksanakan".

Program-program yang telah dilaksanakan dalam rangka implementasi pendidikan karakter dan program PPK di sekolah tersebut diantaranya yaitu:

1) Program Pembelajaran Akademik yaitu: Pembelajaran dikelas seperti biasanya sekolah pada umumnya untuk TKLB dan SDLB, serta untuk SMPLB dan SMLB 40\% akademik dan 60\% keterampilan.

2) Program Keterampilan, pembelajaran untuk meningkatkan kemampuan skill dan kewirausahaan untuk dapat hidup mandiri :

- Keterampilan Tata Boga

- Keterampilan Tata Busana

- Keterampilan Kecantikan

- Keterampilan Sablon

- Keterampilan Komputer grafis

- Keterampilan Rekayasa

- Keterampilan membatik

3) Program Khusus

- A : Orientasi Mobilitas

- B : BKPBI

- C : Bina Diri

- D : Bina Gerak

- Autis : Bina diri dan Bina sosial

4) Program Pengembangan Diri dan

Ekstrakulikuler

- Olah vokal, puisi, menari, melukis, pantomin

- Basket, tenis meja, bulu tangkis, atletik

- IPA, matematika, Karya ilmiah, IT

- Kegiatan kepramukaan

5) Budaya dan Karakter Bangsa

- Upacara Bendera setiap hari senindanTanggal 17 Agustus

- Apel pagi guru, karyawan, dan beserta semua peserta didik, apel siangseluruh guru dan karyawan.

- Berdo'a sebelum dan sesudah belajar

- Pemeriksaan kebersihan kuku, gigi serta pakaian sebelum masuk kelas

- Menyiram Tanaman

- Membersihkan Kelas sebelum dan sesudah belajar-

- Piket peserta didik dan guru

○ Program Membaca 15 menit sebelum pembelajaran

- Menyanyikan 1 lagu daerah/nasional setiap apel pagi

- Gebas (Gerankan Bank Sampah)

- Gebel (Gerakan Bersih Lingkungan)

- Imtaq dan Sholat sunat dhuha( Islam),sembahyang (Hindu), shalat dhuhur berjamaah,

- Membaca buku di perpustakaan

- Kerja bakti sekali sebulan setiap sabtu minggu terakhir. 
- Senam bersama setiap hari sabtu

Berdasarkan uraian diatas dapat disimpulkan bahwa pengimplementasian penguatan pendidikan karakter di SLB Negeri 1 Mataram dilaksanakan melalui program-program yang terintegrasi dengan kegiatankegiatan yang sudah dirancang disekolah dengan artian bahwa disetiap proses disekolah selalu dimasukan nilainila karakter untuk memperkuat pendidikan karakter itu sendiri. Melalui kegiatan atau program pembelajaran disekolah maka penerapan atau implementasian penguatan pendidikan karakter dapat terlaksana.

Penguatan pendidikan karakter bagi anak Tunadaksa dilaksanakan melalui kegiatan pembinaan gerak yang dikhusus untuk siswa yang memiliki keterbatasan gerak atau pisik, dalam kegiatan tersebut pemberian motivasi, masukan, keyakinan dan pengembangan selalu diberikan oleh guru guna mendukung dan memberi kepercayaan diri sehingga terbentuknya keberanian dan mental kuat siswa. Dari kegiatan tersebut dapat dilihat bahwa sikap anak tunadaksa di SLB Negeri 1 Mataram tidak segan untuk melakukan interaksi dengan orang lain, percaya diri dan sikap saling membantu dalam melaksanakan tugas di kelas.

Penguatan pendidikan karakter dilakukan untuk membentuk keperibadian seseorang sehingga dalam pelaksanaan penguatan pendidikan karakter bagi anak Autisyang umumnya mengalami hambatan dalam bidang komunikasi, imajinasi, dan sosialisasi sehingga guru harus melakukan strategi yang tepat untuk menanamkan karakter yang baik kepada siswa yaitu melalui kegiatan bina diri dan bina sosisal dengan proses pembiasaan dan pembudayaan yang baik di sekolah, seperti memberi sapaan dan salam, proses pembimbingan kegiatan dalam menjaga kebersihan dengan bekerja sama, memberikan hal-hal baru dalam pembelajaran, mencontohkan sikap jujur, toleransi, dan pembiasaan melakukan interaksi-interaksi dengan orang lain seperti pada kegitan apel pagi dan kegitan imtaq.

Pada anak yang mengalami gangguan penglihatan atau Tunanetra, penerapan penguatan pendidikan karakter sama halnya dengan penanaman karakter pada siswa lainya yakni dengan menyisipkan nilai-nilai karakter disetiap proses pembelajaran karena perkembangan atau kemampuan anak tunanetra sama halnya dengan anak umumnya hanya saja media yang digunakan berbeda. Kegiatan khusus yang dilakukan dalam pemebalajaran disekolah yaitu kegiatan orientasi mobilitas yang merupakan kemampuan seorang siswa dalam mengenali lingkungannya dengan menggunakan semua indra yang masih ada untuk mengenali setiap benda-benda yang akan dipelajari. Proses penanaman karakter bagi siswa tunanetra di SLB Negeri 1 Mataram dilakuakan dari kegiatan cerita-cerita motivasi, keteladanan yang disampaikan oleh guru.

Berdasarkan paparan diatas, makaimplementasi peraturan Presiden No.87 Tahun 2017 tentang penguatan pendidikan karakter sebagai bentuk penerapan nilai-nilai Pancasila dilakukan dengan penyesuaian melalui program kegiatan disekolah yang dirancang sebelumnya dengan menerapkan 5 nilai utama pendidikan karakter yaitu nilai pertama nilai religius, yang mengajarkan nilai-nilai spiritual melalui kegiatan berdoa bersama sebelum atau sesudah belajar, memberi salam, dan mengikuti kegiatan imtaq di hari jum'at. Kedua, nilai nasionalis seperti mengikuti upacara bendera, merayakan hari besar nasional dan mengenal keberagaman budaya memalalui kegiatan keterampilan yang ada disekolah. Ketiga, nilai integritas yang dimana siswa selalu memberikan salam pada guru, siswa selalu menjaga kebersihan dengan menjalankan jadwal piket di kelas, berpakaian sopan, tepat waktu ke sekolah, selalu antri masuk kelas dan tidak melalakukan pelaggran terhadap aturan sekolah.

Ke empat, nilai mandiri yang selalu diajarkan yaitu sebelum proses pembelajaran siswa di wajibkan untuk membaca buku 15 menit sebelum mulai belajar dan siswa diajarkan kegiatan kewirausahaan untuk memanfaatkan keterampilan yang ada dan kelima, yaitu nilai gotong royong yang selalu diajarkan melalui kegiatan kerja bakti di sekolah secara bersama-sama setiap hari sabtu. Semua kegiatan-kegiatan disekolah yang sudah di programkan merupakan bentuk implementasi peraturan presiden No.87 Tahun 2017 sebagai upaya pengautan pendidikan karakter yang mencerminkan bentuk penerapan nilai-nilai pancasila.

\section{Hambatan dalam penguatan penedidikan karakter untuk siswa berkebutuhan khusus}

Dalam pengimplementasian penguatan pendidikan karakter di SLB Negeri 1 Mataram terdapat beberapa hambatan yang dialami yang diantaranya :

a. Keikutsertaan orang tua dalam mendukung pengutan pendidikan karakter siswa disekolah

Pendidikan pertama yang didapat oleh anak-anak yaitu di lingkungan keluarga. Keterlibatan orang tua sangatlah penting hal ini yang di ungkapkan informan yaitu bapak kepala sekolah bahwa :

"orang tua itu biasanya menganggap pendidikan itu diserahkan sepenuhnya kepada sekolah, biasanya orang tua mengantar siswa dan menjemputnya pulang tanpa mengetahui apa yang telah diperoleh oleh anak di sekolah yang seharusnya dilanjutkan kembali oleh orang tua di rumah sehingga disinilah letak kesulitan yang dihadapi kurangnya kesadaran orang tua".

Keikutsertaan orang tua dalam mendukung setiap program kegitan disekolah masih cukup kurang dirasakan oleh pihak sekolah biasanya dilihat dari tingkat kedisiplinan orang tua saat mengantar siswa ke sekolah yang masih sering terlambat dan masih kurangnya kesadaran orang tua dalam memberikan contoh saat membuang sampah di lingkungan sekolah. 
Kurangnya kepedulian atau dukungan orang tua terhadap pendidikan anak disekolah juga di ungkapkan oleh ibu waka kesiswaan yang menyatakan bahwa:

"ada beberapa orang tua yang memiliki sedikit kesadaran untuk selalu mendukung atau mensupot anaknya karena adanya factor ekonomi yang dialami orang tua dan kadangkadang ada orang tua yang bersikap cuek".

Pengetahuan atau faktor ekonomi yang dialami oleh orang tua siswa dapat menjadi pengaruh kurang adanya dukungan orang tua dalam pelaksanaan program penguatan pendidikan karakter di sekolah yang juga melibatkan kerjasama antara orang tua dengan pihak sekolah dalam proses pelaksanaannya.

b. Kurang adanya kemaksimalan dalaminovasi atau pengembangan pada pelaksanaan penguatan pendidikan karakter disekolah

Nilai-nilai yang ditekankan atau menjadi prioritas dalam pelaksanaanpendidikan karakter secara umum yaitu religius, nasionalis, integritas, mandiri, dan gotong royong, sehingga guru harus mampu merancang satu metode pembelajaran yang mencangkup semua nilainilai karakter tersebut sehingga mampu memperkuat pendidikan karakter yang sudah terprogram sebelumnya. Untuk tercapainya suatu tujuan pemelajaran maka guru dituntuk memiliki kretifitas dan mampu melalukan inovasi sehingga terciptanya proses pembelajaran yang menyenangan untuk membentuk karakter siswa.

Kurannya kemaksimalan dalam inovasi yang dilakukan guru juga terjadi di SLB Negeri 1 Mataram seperti yang dinyatakan oleh bapak kepala sekolah yaitu :

"Kendala dalam pengimplementasian

penguatan pendidikan karakter itu sendiri kurangnya kemaksimalan pelaksanaannya karena terjadi kejenuhan proses palaksanan, jadi pihak sekolah kurang mampu mengembangkan atau berinovasi bahwa pendidikan karakter itu bisa dilakukan dengan berbagai cara tidak mesti dengan teori-teori”.

Dari penjelasan diatas dapat disimpulkan bahwa hambatan yang dialami dalam pengimplementasian Perpres No.87 Tahun 2017 tentang penguatan pendidikan karakter di SLB Negeri 1 Kota Mataram adalah kurannya keikutsertaan orang tua terdapat pentingnya pendidikan karakter yang di dapat oleh siswa disekolah danmasih kurannya kemaksimalan dalam penerapan penguatan pendidikan karakter di pembelajaran oleh pihak sekolah sehigga perlu adanya proses evaluasi dalam pengimplementasian penguatan pendidikan karakter yang akan dilakukan.

Pada setiap proses pengimplementasian Prpres No.87 Tahun 2017 tentang penguatan pendidikan karakter sebagai bentuk penerapan nilai-nilai pancasila yang sudah di rancang pasti memiliki kendala ataupun hambatan yang dialami oleh sekolah terutama sekolah yang diperuntungkkan bagi anak berkebutuhan khusus yang juga memerlukan pendidikan karakter untuk membentuk perilaku yang sesui dengan nilai-nilai pancasila. Hambatan dalam pelaksanaan penguatan pendidikan karakter yang dialami oleh SLB Negeri 1 Mataram yang pertama ialahkurangnya dukungan atau partisipasi orang tua dalam proses pendidikan karakter pada anak yang dilakukan di sekolah

Keterlibatan dan kerja sama dengan orang tua atau wali murid sangat diperlukan dalam pendidikan karakter anak yang dimana dalam Perpres No.87 Tahun 2017 tentang penguatan pendidikan karakter seharusnya dilaksanakan dengan menjalankan kerjasama yang melibatkan pihak sekolah, orang tua dan masyarakat sebagai bentuk dari gerakan revolusi mental. Kurangnya kepedulian orang tua atau wali murid bisa dilihat dari tingkat kedisiplinan orang tua dalam mencontohkan nilai-nilai karakter yang seharusnya ditiru oleh siswa seperti sering terlambat mengantar siswa kesekolah, masih serinnya membuang sampah tidak pada tempatnya dan permasalahan ini menandakan kurannya kedisiplinan orang tua dalam mempehatikan penerapan nilai-nilai karakter yang seharausnya ditanamkan sejak dini pada siswa.Sehingga permasalah ini menjadi hambatan bagi pelaksanaan penguatan pendidikan karakter yang pelajari disekolah.

Kedua, hambatan yang dialami yaitu masih kurannya kemaksimalan dalam inovasi atau pengembangan yang dilakukan pihak sekolah pada proses pengimplemntasian penguatan pendidikan karakter sehingga belum maksimalnya pelaksanaan pendidikan karakter yang dilakukan. Dalam hal ini, pendidikan karakter dilakukan secara terintegrasi dengan program disekolah yang sudah semestinya dilakukan dengan berbagai pengembangan agar siswa tidak cepat merasah jenuh ataupun bosan dengan proses kegaitan yang ada di sekolah.

Kurang maksimalnya dalam berinovasi pada proses pembelajaran sebagai bentuk implementasi pengutan pendidikan karakter yang dilakukan juga tidak terlepas dari pengaruh pendanaanyang dimiliki oleh sekolah sehingga kratifitas yang ingin dilakukan terbatas pelaksanaannya.Pendidikan karakter tidak hanya sekedar teori atau materi yang diajarkan tetapi juga perlu dipraktekkan atau tindakan nyata sebagai bentuk terlaksananya pendidikan karakter, karenanya keterbatasan melakukan inovasi dan krastifitas dapat menjadi penghambat dalam pengimplementasian penguatan pendidikan karakter disekolah.

\section{Solusi dalam mengatasi masalah untuk siswa berkebutuhan khusus}

Mengatasi hambatan atau permasalahan yang di hadapi Sekolah Luar Biasa Negeri 1 Mataram telah melakukan beberapa upaya seperti yang diungkap oleh bapak kepala sekolah bahwa : 
"setiap hambatan dan permasalahan yang ada disekolah kami ini, sebenarnya kami jadikan tantangan untuk memotivasi diri supaya lebih baik lagi dan disini kami telah berupaya untuk mengajar kerja sama orang tua dalam memberikan pendidikan karakter pada siswa dan selalu melakukan pembaharuan dengan memanfaatkan lingkungan sekitar sekolah dalam pendidikan karakter".

Setiap upaya dalam mengatasi hambatan yang dialami dalam proses implementasian penguatan pendidikan karakter di SLB Negeri 1 Mataram sebagai berikut: Pertama, pihak sekolah mengadakan kerjasama dengan orang tua atau wali murid untuk ikut serta dalam penerapan program-program pembelajaran disekolah dan selalu memberikan himbauan kepada orang tua atau wali murid bahwa pentingnya dukungan atau peran orang tua dalam penerapan pendidikan karakter untuk anak.

Kedua, mengatasi kurangnya kemaksimalan dalam pelaksanaan program penguatan pendidikan karakter pihak sekolah selalu mengevaluasi dan terus berusaha mengembangkan setiap proses pembelajaran yang diberikan kepada peserta didik dengan mengadakan kegiatan-kegiatan baru dengan memanfaatkan lingkungan disekitar sekolah dan melibatkan pihak instansi-instansi terkait untuk meningkatkan pengetahuan sehingga nilai karakter yang sesuai dengan nilai-nilai pancasila dapat terlaksanakan dengan baik. Pada setiap kendala yang dihadapi oleh pihak sekolah dalam pengimpementasian penguatan pendidikan karakter tentu harus memerlukan kerja sama baik dengan seluruh warga sekolah maupun orang tua siswa.

Setiap kendala atau hambatan dalam implementasi penguatan pendidikan karakter di sekolah, harus mampu dihadapi dan mencari solusi dalam mengatasi hambatan tersebut sehingga pengimplementasian penguatan pendidikan karakter tidak terhambat. Karenanya, sekolah telah berupaya dalam mengatasi kendala tersebut yaitu dengan berupaya memprogramkan kegiatan yang melibatkan pihak sekolah supaya dapat berkerja sama dengan orang tua ataupun lingkungan masyarakat seperti mendatangkan dinas-dinas kesehatan dan pisikologi yang dimana hal tersebut juga mengikutsertakan orang tua sehingga orang tua dapat mendukung pendidikan karakter yang didapatkan oleh anak-anakya.

Disamping itu nilai karakter gotong royong dan kemandirian yang mencerminkan nilai pancasila juga bisa didapatkan dalam kegitan tersebut. Pihak sekolah juga selalu menghimbau kepada setiap orang tua atau wali murid untuk memberikan contoh dari hal-hal kecil yeng mampu menumbuhkan karakter baik seperti disiplin dalam mengantar siswa kesekolah dan membuang sampah harus pada tempatnyadan dalam pendidikan karakter anak berkebutuhan khusus di SLB
Negeri 1 Mataram juga bisa dilakukan dilingkungan keluarga ketika siswa kembali ke rumah, dalam hal ini orang tua harus mampu mencerna proses pendidikan karakter yang baik sehingga mampu diterapkan dan ditiru oleh siswa.

Pada permasalahan kurannya kemaksimalan pengembangan dalam pendidikan karakter maka pihak sekolah berusaha mengatasi dengan selalu melakukan evaluasi program kegiatan disekolah setiap tahunya sehingga tercermin nilai karakter kerja keras dan bermusyawarah antar warga sekolah.Selain itu, pihak sekolah selalu memanfaatkan lingkungan sekolah dan melakukan inovasi dari hal kecil yang ada disekolah.

Dengan mengenal lingkungan yang ada disekitar sekolah siswa tentu akan banyak belajar karena di berbagai sudut sekolah selalu dipasangkan seloganselogan ataupun kata-kata motivasi utnuk membentuk karakter siswa melalui media gambar dan tulisan yang ada. Maka dapat disimpulkan bahwa setiap kendala harus ada solusi yang terus dilakukan oleh pihak sekolah yaitu dengan melakukan kerja sama yang melibatkan orang tua dan melalukan pengembangan pada proses pembelajaran pendidikan karakter di sekolah yang mencerminkan nilai-nilai Pancasila.

\section{TEMUAN ATAU DISKUSI}

Peraturan Peresiden No.87 Tahun 2017 tentang pengutan pendidikan karakter merupakan bagian dari Gerakan Nasional Revolusi Mental yang dilakukan melalui harmonisasi (etik dan spiritual), olah rasa (estetik), olah pikir (literasi dan numerasi), dan olah raga (kinestetik) sesuai dengan nilai-nilai Pancasila dan melibatkan kerjasama antara sekolah, keluarga, dan masyarakat. Untuk itu, pentingnya implementasi atau penerapan disetiap jenjang pendidikan agar terwujudkan kompetensi siswa dalam menerapkan nilainilai Pancasila, meliputi nilai religius, jujur, toleran, disiplin, bekerja keras, kreatif, mandiri, demokratis, rasa ingin tahu, semangat kebangsaan, cinta tanah air, menghargai prestasi, komunikatif, cinta damai, gemar membaca, peduli lingkungan, peduli sosial, dan bertanggung jawab. Berdasarkan data di lapangan bahwa pengimplementasian penguatan pendidikan karakter di Sekolah Luar Biasa Negeri 1 Mataram dilaksanakan melalui program-program yang terintegrasi dengan proses kegaitan pebelajaran di sekolah baik kegiatan intrakurikuler, kegiatan kokurikuler, dan kegiatan ekstrakurikuler sebagaimana yang tercantul dalam Peraturan Presiden No.87 Tahun 2017. Adapun program yang sudah dirancang yang terintegrasi dengan penguatan pendidikan karakter yaitu:

a. Program pembelajaran akademik

Program pembelajran akademik di SLB Negeri 1 Mataram merupakan proses kegiatan pembelajaran yang dilakukan didalam kelas baik untuk tingkat TKLB, SDLB, SMPLB, dan SMLB selalu dimulai dengan penanaman nilai-nilai karakter seperti mengantri saat masuk 
kedalam kelas, menjaga kebersihan kelas, dan berdoa bersama sebelum maupun sesuda proses pembelajaran dilakukan sehingga tumbuhlah nilai toleransi, nilai keagamaan, menghormati serta menjaukan dari dari perilaku anarkis. Memberikan aktivitas realistis di luar kelas. Pembelajaran yang diselesaikan adalah $75 \%$ pengalaman dan 25\% teori. Praktik pembelajaran dilakukan dengan program dinamika kelompok untuk mendongkrak prestasi non akademik siswa. Beberapa kegiatan pembelajaran antara lain: membatik, memasak, merias wajah, membuat kerajinan dari bahan bekas dan membuat keranjang perlengkapan pernikahan.[9] Pembelajaran anak berkebutuhan khusus harus mencakup setidaknya 5 (lima) aspek dalam pengembangan program pembelajaran individu: 1) tingkat keterampilan anak saat ini (diperoleh dari hasil tes), mengidentifikasi kekuatan, keterbatasan dan aspek yang dibutuhkan anak. 2) Rumusan tujuan umum (goal) yang akan dicapai dalam satu tahun dan dijabarkan lebih rinci dalam mengidentifikasi tujuan (objektif) tertentu. 3) Pendekatan yang digunakan untuk meningkatkan keterampilan anak. 4) Perkiraan awal operasi dan waktu yang dihabiskan untuk memberikan layanan. 5) Prosedur penilaian apa yang digunakan untuk menilai kinerja atau kegagalan layanan anak.[10]

b. Program Keterampilan

Program keterampilan merupakan program pada proses pembelajaran siswa untuk meningkatkan kemampuan skill untuk dapat hidup mandiri, penanaman nilai karakter pada setiap pelaksanan keterampilan ini yaitu nilai karakter kemandirian yang mana setiap proses kegiatan siswa dituntut berusaha melatih diri untuk mengasah kempuan yang dimiliki. Dalam proses pelaksanaan kegiatan keterampilan ini nilai-nilai kebudayaanpun diajarkan seperti keterampilan membantik, tata busana dan sebagainya, agar siswa dapat mengenal indonesia dengan kebudayaan yang dimiliki sehingga muncul nilai kecintaan terhadap bangsa dan Negara. Anak kebutuhana khusus ini harus mampu menerapkan kemampuan keterampilan sesuai kemampuan mereka.[11] anak berkebutuhan khusus perlu diberikan perkenalan kemampuan mereka atau ketrampilan mereka lebih mahir pada ketrampilan memasak, menjahit, melukis dan lainnya.[12];[13]

c. Program Khusus

Program khusus merupakan program yang dirancang untuk mengembangkan dan latihan dalam pengetahuan, keterampilan, nilai dan sikap bagi anakanak berkebutuhan Khusus sehingga tidak ada hambatan bagi mereka untuk melakukan kegiatan rutin harian seperti bina komunikasi persepsi bunyi irama, bina diri, bina gerak, dan bina sosial sehingga siswa mampu bersikap disiplin, mampu berkerja keras, mandiri, berkomunikatif dan peduli sosial yang tinggi. Secara keseluruhan, ciri pendidikan karakter di sekolah dasar inklusi di Kabupaten Banyumas menggunakan model kebiasaan untuk anak berkebutuhan khusus. Penerapan pendidikan karakter yang digunakan menggunakan teknik blended learning, pengembangan diri dan distribusi waktu. Tantangan yang dihadapi guru dalam memadukan pendidikan karakter adalah keterbatasan keterampilan bagi siswa ABK, pemahaman siswa ABK yang terbatas, keterbukaan orang tua terhadap perkembangan anak yang kurang memadai, serta keterbatasan tenaga dan waktu guru.[14];[15]

d. Program Pengembangan Diri dan ekstrakulikuler

Program pengembangan diri dan ekstrakulikuler merupakan program kegiatan pendidikan yang dilaksanakan diluar mata pelajaran untuk membantu pengembangan peserta didik sesui dengan kebutuhan, bakat, serta minat yang dimiliki oleh peserta didik. Penanaman penguatan pendidikan karakter melalui program pengembangan diri dan ekstrakulikuler dilakukan dengan berupaya memberikan keteladanan, membangun kemauan dan mengembangkan kreatifitas siswa dalam kegiatan pembelajaran. Ekstrakurikuler musik merupakan praktik pengembangan diri yang digunakan di SLB sebagai sarana penciptaan karakter. Pembinaan karakter terdiri dari membimbing siswa untuk mengalami dan membiasakan menggunakan sikap/karakter dalam proses pembelajaran seni musik.[16] Lainnya menjelaskan beberapa hal yaitu 1. Kegiatan ekstrakurikuler meliputi program-program reguler antara lain $4 \mathrm{~S}$ (senyuman, salam, dan salam), sholat berjamaah, mengaji dan salat harian sebelum pelajaran dimulai dan setelah pengalaman selesai, sholat dhuha berjamaah, mauidah hasanah, kuis agama, pengajian Quran, hafalan surat pendek, PHBI (Maulid Nabi dan Muharram 1 Peringatan). 2) Praktik pertumbuhan spiritual dilakukan dalam tiga tahap, yaitu tahap penguatan gagasan moralitas (pengetahuan), tahap implementasi (melakukan) tahap keberadaan (being), dan tahap pengembangan suasana religius. 3). Faktor pendukung dalam pelaksanaan ekstrakurikuler PAI antara lain: keaktifan dan kegairahan siswa, kerjasama dengan semua guru, dukungan wali siswa, dana sekolah, dukungan semua pihak. Faktor penghambat meliputi; Kebutuhan siswa sangat bervariasi, sehingga guru harus memperhatikan setiap pelayanan dan sarana prasarana khusus untuk anak berkebutuhan khusus yang kurang mendukung.[17]

e. Budaya dan karakter bangsa

Program kegiatan budaya dan karakter bangsa merupakan program yang dirancang untuk penerapan pendidikan karakter disekolah seperti pelaksanaan upacara bendera yang mana kegiatannya dilakukan setiap hari senin. Hal ini dilakukan agar nilai nasionalisme siswa tertanam dengan kuat agar dapat merasakan bagaimana pahlawan-pahlawan dulu memperjuangkan kemerdekaan bangsa, kegiatan imtaq 
yang dilakukan tidak lain untuk menanamkan nilai religius pada siswa dengan beriman dan betakwa kepada Tuhan serta dapat memahami keberagaman dalam beragama, penanamansikap disiplin dan gotong royong seperti melakukan Gebas (Gerankan Bank Sampah) dan Gebel (Gerakan Bersih Lingkungan) yang dilakukan sekali sebulan setiap sabtu minggu terakhir.Kemudian kegiatan membaca buku perpustakaan dengan artian sebelum memulai pembelajaran siswa di wajibkan melakukan program membaca 15 menit untuk menanamkan nilai karakter kemandirian dan mengajarkan nilai integritas kepada siswa. Hal tersebut sejalan dengan pendapat bahwa Pendidikan karakter bangsa dengan mendampingi siswa ABK dengan siswa normal, melibatkan kasih sayang, semangat dan fokus tanpa kecemburuan kepada siswa reguler lainnya.[18][19]

Pendidikan Pancasila dan Kewarganegaraan di Indonesia dirancang untuk mempersiapkan orang-orang yang baik, yaitu orang-orang yang mencintai negaranya, yang berjiwa patriotisme, dan juga rasa orang tua yang terwujud dalam sikap disiplin, jujur dan toleran. Semua warga negara, termasuk anak-anak dengan kebutuhan unik di semua tingkat pendidikan dasar, menengah dan tinggi, harus dibekali dengan pendidikan pancasila dan kewarganegaraan. Patriotisme dikaitkan dengan eksistensi domestik sehingga Pendidikan Pancasila dan Kewarganegaraan harus ditanamkan pada anak berkebutuhan khusus di sekolah inklusif yang berkarakter nasional. Selain itu sekolah adalah sekolah yang bertujuan untuk memastikan bahwa anak-anak berkebutuhan khusus menerima layanan pendidikan untuk memenuhi kebutuhannya. Karenanya, karakter nasional harus disesuaikan dengan ciri unik setiap anak berkebutuhan khusus.[20]

Pada proses implementasi penguatan pendidikan karakter sebagai bentuk penerapan nilai Pancasila yang dilakukan di kelas Tunarungu yaitu guru selalu berinteraksi bersama siswa dengan sistem isyarat, tulisan maupun suara dengan memanfaatkan sisa pendengaran yang dimiliki siswa, hal ini biasa dilakukan dalam proses pembelajaran. Melalui proses intraksi dengan siswa guru selalu menyisipkan dan mencontohkan nilai-nilai karakter melalui gerakan yang akan mampu di ingat dan dipahami oleh siswa seperti selalu bersikap jujur, berperilaku sopan bertemu guru atau orang lain,disiplin saat mengikuti pembelajaran dan hal tersebut dapat dilaksanakan oleh siswa dengan baik karena siswa yang mengalami tunarungu memiliki potensi perkembangan yang sama layaknya anak-anak lain hanya saja kemapuan tersebut terhambat karena masalah pendengaran maupun kemampuan bicara yang dimiliki oleh siswa tunarungu.

Pada anak Tunagrahita, kegiatan penguatan pendidikan karakter yang dilakukan tidak hanya sekedar di ucapkan atau berisi materi tetapi guru selalu memberikan contoh atau pengamalan pada siswa, dalam proses ini pembiasaan atau kegiatan yang secara berulang-ulang agar dapat dimaknai oleh siswa baik melalui kegiatan keagamaan, sosial maupun keterampilan pada proses pembelajaran didalam kelas. Nilai kemandirian sangat ditekankan oleh guru dalam kegiatan pembinaan terhadap anak tunagrahita seperti kegiatan membaca sebelum dimulainya kegiatan belajar, menyanyikan lagu kebangsaan, serta berani untuk berbicara di depan umum hal ini agar siswa dapat mengembangkan kemampuan yang dimilikinya. Penerapan nilai karakter yang dilaksanakan harus disesuaikan dengan kempuan yang dimiliki siswa tunagrahita.

\section{E. SIMPULAN DAN SARAN}

Hasil peneilitian ini memberikan dampak bahwa revolusi mental melalui penguatan pendidikan karakter untuk siswa berkebutuhan khusus dapat dilakukan melalui program-program yang terintegrasi dengan proses kegaitan pebelajaran di sekolah meliputi kelima nilai utama penguatan pendidikan karakter yaitu nilai religius, nasionalisme, gotong royong, integritas, dan mandiri melalui program pembelajaran akademik, program keterampilan, program khusus, pengembangan diri dan ekstarakulikuler, budaya dan karakter bangsa. Selain itu, juga pihak sekolah berupaya memprogramkan kegiatan yang melibatkan pihak sekolah dapat berkerja sama dengan orang tua ataupun lingkungan masyarakat. Hambatan yang terjadi adalah kurangnya dukungan atau partisipasi orang tua dalam proses pendidikan karakter pada anak yang bisa menjadi permasalah ataupun hambatan bagi siswa dalam penerapan nilai karakter di lingkungan keluarga dan masyarakat selain itu, masih kurannya kemaksimalan dalam inovasi atau pengembangan yang dilakukan pihak sekolah pada proses pengimplemntasian penguatan pendidikan karakter sehingga belum maksimalnya pelaksanaan pendidikan karakter yang dilakukan.

Dengan demikian menyarakan bahwa masih perlunya penambahan program-program baru yang benar-benar memfokuskan dalam penerapan pengutan pendidikan karakter yang belum pernah dilakukan disekolah. Pihak sekolah dan orang tua atau wali murid harus selalu menjalin kerjasama dan memberikan dukungan untuk melaksanakan program yang sudah dirancang dalam pengimplementasian pengutan pendidikan karakter bagi anak berkebutuhan khusus dan mampu memenfaatkan lingkungan masyarakat yang baik untuk pengembangan karakter anak.

\section{UCAPAN TERIMA KASIH}

Penulis mengucapkan terima kasih kepada semua pihak yang telah memberikan data dan informasi sehingga penelitian ini selesai dengan baik. 


\section{DAFTAR RUJUKAN}

[1] S. Musawwamah and T. Taufiqurrahman, "Penguatan Karakter Dalam Pendidikan Sistem Persekolahan (Implementasi Perpres Nomor 87 Tahun 2017 Tentang Penguatan Pendidikan Karakter)," NUANSA J. Penelit. Ilmu Sos. dan Keagamaan Islam, vol. 16, no. 1, pp. 40-54, 2019.

[2] M. Neli, J. Indrawadi, and I. Isnarmi, "Penguatan Pendidikan Karakter Mandiri Anak Berkebutuhan Khusus Tunagrahita di Panti Sosial Bina Grahita 'Harapan Ibu' Padang," J. Civ. Educ., vol. 3, no. 2, pp. 172-177, 2020.

[3] B. Pamungkas, "Urgensi Pendidikan Karakter untuk Mengoptimalkan Layanan Pendidikan Bagi Siswa Berkebutuhan Khusus di Sekolah Inklusif," 2016.

[4] S. Soemantri, "PBL dengan pendekatan realistic mathematic meningkatkan nilai karakter siswa berkebutuhan khusus," Math Didact. J. Pendidik. Mat., vol. 5, no. 1, pp. 1-12, 2019.

[5] N. Rofisian, "Konsep pendidikan karakter pada anak berkebutuhan khusus," Pros. Konf. Ilm. Dasar, vol. 1, pp. 19-25, 2018.

[6] D. K. Albertus, "Pendidikan karakter: strategi mendidik anak di zaman global," Jakarta: Grasindo, 2007.

[7] K. P. Perempuan, P. Anak, and B. P. Statistik, "Pembangunan manusia berbasis gender," Jakarta Kementeri. Pemberdaya. Peremp. dan Perlindungan Anak, 2018.

[8] D. R. Desiningrum, "Psikologi anak berkebutuhan khusus." psikosain, 2017.

[9] R. D. Miftakhi and M. Hendrik, "Implementasi Model Pembelajaran Dinamika Kelompok dalam Meningkatkan Motivasi Berprestasi Bidang Non Akademik Anak Berkebutuhan Khusus di SLB YPAC Pangkalpinang," J. Pendidik. Kebutuhan Khusus, vol. 3, pp. 1-5, 2019.

[10] M. Assjari, "Program Pembelajaran Individual," Dep. Pendidik. Nasional, Direktorat Jendral Manaj. Pendidik. Dasar dan Menengah, Direktorat Pembin. Sekol. Luar Biasa, 2005.

[11] M. Iswari, "Pendidikan Kecakapan Hidup Bagi Anak Berkebutuhan Khusus," 2007.

[12] A. Mahabbati, "Layanan Pendidikan untuk Anak Berkebutuhan Khusus dan Pendidikan Inklusif," Pap. disampaikan dalam PPM Sos. dan Identifikasi Anak Berkebutuhan Khusus di Sekol. Umum, Bantul, 2013.

[13] N. Abdullah, "Mengenal anak berkebutuhan khusus," Magistra, vol. 25, no. 86, p. 1, 2013.

[14] F. Yatmiko, E. Banowati, and P. Suhandini, "Implementasi pendidikan karakter anak berkebutuhan khusus," J. Prim. Educ., vol. 4, no. 2, pp. 77-84, 2015.

[15] A. Riadin, M. Misyanto, and D. S. Usop, "Karakteristik Anak Berkebutuhan Khusus di Sekolah Dasar Negeri (Inklusi) di Kota Palangka Raya," Anterior J., vol. 17, no. 1, pp. 22-27, 2017.

[16] M. Rifa, "Pembentukan Karakter Anak Berkebutuhan Khusus Tunanetra Melalui Seni Musik Di SLB Kuncup Mas Banyumas." IAIN Purwokerto, 2016.
[17] S. M. Hasanah, "Pembinaan Akhlak Siswa Berkebutuhan Khusus Melalui Kegiatan Ekstrakurikuler Pai Di Sdlb Islam Yasindo Malang," J-PAI J. Pendidik. Agama Islam, vol. 3, no. 2, 2017.

[18] I. L. Erawati, "Pendidikan Karakter Bangsa pada Anak Berkebutuhan Khusus dalam Pendidikan Inklusif." UNIVERSITAS LAMPUNG, 2016.

[19] F. Fitriani and A. Sakban, "Penerapan Pendidikan Karakter Terhadap Efektifitas Penggunaan Kurikulum 2013 Dalam Persepektif Moral Bangsa di SMA Nurul Jannah NW Ampenan," Civ. Pendidikan-Penelitian-Pengabdian Pendidik. Pancasila dan Kewarganegaraan, vol. 6, no. 1, pp. 1-7, 2018.

[20] T. Desti, "Peran Pendidikan Pancasila dan Kewarganegaraan dalam Menanamkan Karakter Kebangsaan pada Anak Berkebutuhan Khusus di Sekolah Inklusi," 2017. 